\title{
Citrus exocortis viroid and Hop Stunt viroid Doubly Infecting Grapevines in Brazil
}

\author{
Marcelo Eiras ${ }^{1}$, Maria Luisa P.N. Targon ${ }^{2}$, Thor V.M. Fajardo ${ }^{3}$, Ricardo Flores ${ }^{4}$ \& Elliot W. Kitajima ${ }^{5}$ \\ ${ }^{1}$ Centro de Pesquisa e Desenvolvimento de Sanidade Vegetal, Instituto Biológico, Av. Conselheiro Rodrigues Alves, 1252, \\ CEP 04014-002, São Paulo, SP, Brasil; ${ }^{2}$ Centro APTA Citros Sylvio Moreira, Instituto Agronômico de Campinas, Cx. Postal 04 , \\ CEP 13490-970, Cordeirópolis, SP, Brasil; ' ${ }^{3}$ Embrapa Uva e Vinho, Rua Livramento, 515, CEP 95700-000, Bento Gonçalves, RS, Brasil; \\ ${ }^{4}$ Instituto de Biologia Molecular e Celular de Plantas, CSIC, Universidade Politécnica de Valencia, Av. de los Naranjos, Valencia 46022,

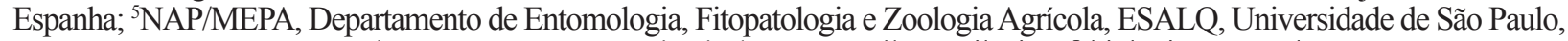 \\ Cx. Postal 09, CEP 13418-900, Piracicaba, SP, Brasil, e-mail: eiras@biologico.sp.gov.br
}

(Accepted for publication on 21/09/2006)

Author for correspondence: Marcelo Eiras

EIRAS, M., TARGON, M.L.P.N., FAJARDO, T.V.M., FLORES, R. \& KITAJIMA, E.W. Citrus exocortis viroid and Hop stunt viroid doubly infecting grapevines in Brazil. Fitopatologia Brasileira 31:440-446. 2006.

\begin{abstract}
Viroids, non-protein-coding small (246-401 nt) circular single-stranded RNAs with autonomous replication, are currently classified into two families. Within the family Pospiviroidae, Citrus exocortis viroid (CEVd) belongs to the genus Pospiviroid while Hop stunt viroid (HSVd) is the single member of the genus Hostuviroid. These pathogens are distributed worldwide and infect a large number of hosts. In Brazil, isolates of CEVd and HSVd have been detected in both citrus and grapevine. To characterize and study the genetic variability of these viroids, total RNA from leaves of grapevine Vitis vinifera 'Cabernet Sauvignon' and V. labrusca 'Niagara Rosada' from Bento Gonçalves, RS, was used as a template for RTPCR amplification with specific primers for the five viroids described infecting grapevines [HSVd, CEVd, Grapevine yellow speckle viroid 1 (GYSVd-1), Grapevine yellow speckle viroid 2 (GYSVd-2) and Australian grapevine viroid (AGVd)]. Leaf samples of Citrus medica infected with CEVd from São Paulo were also analyzed. The resulting products were separated by agarose gel electrophoresis and DNA fragments of the expected size were eluted, cloned and sequenced. The grapevine samples analyzed were doubly infected by CEVd and HSVd. A phylogenetic analysis showed that the Brazilian grapevine HSVd variants clustered with other grapevine HSVd variants, forming a specific group separated from citrus variants, whereas the Brazilian CEVd variants clustered with other citrus and grapevine variants.
\end{abstract}

Additional keywords: CEVd, HSVd, Pospiviroid, Hostuviroid, Pospiviroidae.

\section{RESUMO}

Videiras duplamente infectadas pelo Citrus exocortis viroid e Hop stunt viroid no Brasil

Os viróides são os menores fitopatógenos conhecidos, sendo constituídos de uma molécula de RNA fita simples, circular, com forte estrutura secundária. Possuem genomas que variam entre 246 e 401 nucleotídeos e, por não traduzirem proteínas próprias, são totalmente dependentes da célula hospedeira para sua replicação. São classificados em duas famílias e sete gêneros. O Citrus exocortis viroid (CEVd) pertence ao gênero Pospiviroid, enquanto o Hop stunt viroid (HSVd) é o único membro do gênero Hostuviroid, ambos pertencentes à família Pospiviroidae. Estes patógenos apresentam ampla distribuição mundial e infectam um grande número de hospedeiras. No Brasil, isolados do CEVd e do HSVd foram detectados em citros e videiras. Com o objetivo de caracterizar e estudar a variabilidade genética destes viróides, promoveu-se extração de RNA total de folhas de videira Vitis vinifera 'Cabernet Sauvignon' e V. labrusca 'Niagara Rosada' provenientes de Bento Gonçalves, RS, e RT-PCR com oligonucleotídeos específicos para os cinco viróides já descritos em videira [HSVd, CEVd, Grapevine yellow speckle viroid 1 (GYSVd-1), Grapevine yellow speckle viroid 2 (GYSVd-2) e Australian grapevine viroid (AGVd)]. Amostras de folhas de Citrus medica infectadas pelo CEVd provenientes de São Paulo também foram analisadas. Os fragmentos de DNA amplificados foram eluídos, clonados e seqüenciados. As análises das seqüências revelaram que as amostras de videira estavam duplamente infectadas com o CEVd e HSVd. As análises filogenéticas mostraram que os clones de HSVd de videira aqui caracterizados agruparam-se com outros variantes de videira, formando um grupo separado de um segundo formado por variantes de citros. Já os clones de CEVd de videira agruparam-se com isolados de citros e videira.

Palavras-chave adicionais: CEVd, HSVd, Pospiviroid, Hostuviroid, Pospiviroidae.

\section{INTRODUCTION}

Viroids are non-protein-coding, small (246-401

*Part of the Doctoral Thesis of the first author. ESALQ, Universidade de São Paulo, Piracicaba, SP. 2006. nucleotides), circular single-stranded RNAs, adopting compact folding as a result of their high self-complementarity. They have autonomous replication and depend on interaction with host factors to complete their infectious cycle (Flores et al., 2005a).

Viroids are currently classified according to their 
molecular and biological properties into the families Pospiviroidae, with five genera (Pospiviroid, Hostuviroid, Cocadviroid, Apscaviroid, and Coleviroid), or Avsunviroidae with the genera Avsunviroid and Pelamoviroid (Flores et al., 2005b). Members of the family Pospiviroidae present some characteristics such as rod-like or quasi-rod-like secondary structure with five structural domains (terminal left, pathogenic, central, variable and terminal right) and a central conserved region (CCR) within the central domain (C); lack of ribozyme activity, and replication in the nucleus by an asymmetric rolling-circle pathway. Members of the family Avsunviroidae lack a CCR, are able to self-cleave in both polarity strands through hammerhead ribozymes and replicate in the chloroplasts by symmetric rolling circle pathway (for a review, see Flores et al., 2005a).

Within the family Pospiviroidae, Citrus exocortis viroid (CEVd) belongs to the genus Pospiviroid, while Hop stunt viroid (HSVd) is the single member of the genus Hostuviroid. In the TL (terminal left) domain, CEVd has a terminal conserved region (TCR) motif, while HSVd has a terminal conserved hairpin (TCH) motif (Flores et al., 2005b).

CEVd and HSVd are distributed worldwide and infect a large number of hosts (Singh et al., 2003). HSVd was the first viroid described in grapevines, in Japan (Shikata et al., 1984; Sano et al., 1985). After its description, other viroid species were reported, including CEVd (Flores et al., 1985; García-Arenal et al., 1987) and three members of the genus Apscaviroid that occur exclusively in grapevine: Grapevine yellow speckle viroid 1 (GYSVd-1), Grapevine yellow speckle viroid 2 (GYSVd-2) and Australian grapevine viroid (AGVd) (Rezaian et al., 1992; Little \& Rezaian, 2003). Despite the stunting and yellowing symptoms that HSVd induces in cucumber, no disease symptoms are observed in grapevines infected by this viroid. CEVd was also isolated from symptomless grapevines in Spain, Australia and California (García-Arenal et al., 1987; Rezaian et al., 1988; Semancik and Szychowski, 1992).

In Brazil, isolates of CEVd and HSVd have been detected in citrus (Targon et al., 2003) and in grapevine (Fonseca\& Kuhn, 1994). Here we showed the characterization of these viroids in grapevines Vitis vinifera 'Cabernet Sauvignon' and $V$. labrusca 'Niagara Rosada' from Bento Gonçalves, RS, Brazil. The genetic variability of CEVd and HSVd isolates from grapevines is also discussed.

\section{MATERIAL AND METHODS}

\section{Samples}

Leaf samples (5 g) of grapevine Vitis vinifera 'Cabernet Sauvignon' (one sample, without visible symptoms of viroid infection) and $V$. labrusca 'Niagara Rosada' (one sample, displaying yellow speckles) were collected from the Vitis collection of Embrapa Uva e Vinho, Bento Gonçalves, RS, Brazil. Two leaf samples of Citrus medica (CitE01 and CitE02) infected with CEVd were also collected in the Citrus collection of the
Centro APTA Citros Sylvio Moreira, Cordeirópolis, SP, Brazil.

\section{RNA extraction and RT-PCR}

Total RNA was extracted according to method 4 described by Rowhani et al. (1993), designed to prevent tissue oxidation. After extraction, total RNA was purified by chromatography on cellulose CF11 (Whatman), recovered by ethanol precipitation and resuspended in $250 \mu \mathrm{l}$ of sterile water (Flores et al., 1985). The resulting RNA preparations were subjected to RT-PCR amplification using specific primers for the five viroid species reported in grapevine: HSVd, CEVd, Grapevine yellow speckle viroid 1 (GYSVd-1), Grapevine yellow speckle viroid 2 (GYSVd-2) and Australian grapevine viroid (AGVd) (Table 1). The CEVd and HSVd primers were designed based on the CCR region of these viroid species, while the primers for GYSVd-1, GYSVd-2 and AGVd were used according to Rezaian et al. (1992).

TABLE 1 - Primers used for the RT-PCR amplification of the grapevine viroids

\begin{tabular}{|c|c|c|c|}
\hline Viroids & Primers $\left(5^{`} \rightarrow 3^{\prime}\right)$ & Polarity & $\begin{array}{l}\text { PCR product } \\
\text { length (bp) }\end{array}$ \\
\hline \multirow[t]{2}{*}{ HSVd } & actcttctcagaatccagcgag & + & $297-302$ \\
\hline & tgccccggggctcctttctcaggt & - & \\
\hline \multirow[t]{2}{*}{ CEVd } & ggaaacctggaggaagtcg & + & $369-375$ \\
\hline & ccggggatccetgaagga & - & \\
\hline \multirow[t]{2}{*}{ GYSVd-1* } & gaggtcctcggatcac & + & 222 \\
\hline & agagcgcaatgctgaataggc & - & \\
\hline \multirow[t]{2}{*}{ GYSVd-2* } & ttgagg cccggcgaaacgc & + & 363 \\
\hline & accggcttcggagatagaag & - & \\
\hline \multirow[t]{2}{*}{ AGVd* } & gtcgacgaagggtcctcagcagagcacc & + & 369 \\
\hline & gtcgacgacgagtcgccaggtgagtctt & - & \\
\hline
\end{tabular}

First cDNA strands were synthesized using $0.25 \mathrm{ng}$ of total RNA from each sample with the "Preamplification System for First Strand cDNA Synthesis" (Invitrogen) according to the manufacturer's instructions and using specific primers (Table 1). PCR was carried out using 10 $\mu \mathrm{l}$ of the cDNA mix, $10 \mathrm{ng} / \mu \mathrm{l}$ of each pair of primers (Table 1), 1 unit of Taq DNA polymerase (Invitrogen), $1 \mu$ of the deoxynucleotide triphosphate mixture $(0.03 \mathrm{M})$ and $5 \mu \mathrm{l}$ of buffer (Invitrogen). Samples were placed in a PTC-100 thermocycler (MJ Research) and after an initial denaturing step at $94{ }^{\circ} \mathrm{C}$ for $2 \mathrm{~min}$, the amplification profile consisted of 35 cycles of $40 \mathrm{~s}$ at $94{ }^{\circ} \mathrm{C}, 30 \mathrm{~s}$ at $60^{\circ} \mathrm{C}$, and $1 \mathrm{~min}$ at 72 ${ }^{\circ} \mathrm{C}$ with a final extension step at $72{ }^{\circ} \mathrm{C}$ for $10 \mathrm{~min}$. Amplified DNA fragments were subjected to electrophoresis in a $1 \%$ agarose gel stained with ethidium bromide $(0.01 \%)$ and visualized in a UV transilluminator. The expected sizes for the PCR products are indicated in the Table 1.

\section{Cloning and sequencing}

The amplified RT-PCR products were purified from the agarose gel using the "Concert Rapid Gel Extraction System kit" (Life Technologies), cloned into the pGEM- 
$\mathrm{T}$ Easy vector (Promega) and used for transformation of competent E. coli cells (DH5- $\alpha$ ). The inserts of the recombinant plasmids were sequenced by the terminal chain reaction technique, using an $\mathrm{ABI} 3700$ automated sequencer and the "ABI Prism Big Dye Terminator Cycle Sequencing Ready Reaction kit - Ampli Taq DNA polymerase" (Applied Biosystem) according to the manufacturer's instructions.

\section{Sequence comparisons and phylogenetic analysis}

Nucleotide sequences [four variants of HSVd (one of 'Niagara Rosada' and three of 'Cabernet Sauvignon'), five variants of CEVd (one of 'Niagara Rosada' and four of 'Cabernet Sauvignon'), both isolated from a unique plant of each grapevine variety, and two CEVd variants isolated from citrus] were aligned using the Sequencer 3.1 program (Gene Codes Corporation). The sequencing quality threshold was 350 bases with Phred $>20$. Comparisons with other sequences from GenBank were performed using the BLASTn program of the National Center for Biotechnology Information (NCBI). Multiple alignments were obtained with ClustalX 1.8 and the identity (in \%) was determined using the GeneDoc program (Nicholas et al., 1997). The GenBank accession numbers of the nucleotide sequences of the full-length viroids used for phylogenetic analysis are presented in Table 2. Phylogenetic trees were constructed using the MEGA 3.2 program (Kumar et al., 2004) using the neighbor-joining method with bootstrap values (in \%) calculated for 2000 replications.

The predicted secondary structures of minimal free energy of the Brazilian HSVd and CEVd variants from grapevine, reported here, were obtained with the MFold program for circular molecules (Zuker, 1989) and visualized with the RNAviz program (De Rijk \& De Wachter, 1997).

\section{RESULTS AND DISCUSSION}

RT-PCR and sequence analysis revealed that the two grapevine plants, 'Cabernet Sauvignon' without symptoms and 'Niagara Rosada' presenting yellow speckles (Figure 1), were doubly infected by CEVd and HSVd. These results confirm a previous report of double viroid infection in grapevine 'Cabernet Sauvignon' by Fonseca \& Khun (1994) in the South of Brazil, and extend the same case of double-infection to grapevine $V$. labrusca 'Niagara Rosada'. Despite the yellow speckle symptoms observed in this variety, neither the grapevine viroids GYSVd-1 and GYSVd-2, usually associated with this symptomathology, nor the asymptomatic AGVd, were detected. Normally, grapevine-infecting viroids do not induce symptoms in this host with the exception of the synergism reported between Grapevine fanleaf virus (GFLV, a nematode-transmitted virus) and GYSVd-1, which results in severe vein-banding (Szychowski et al., 1995). Although GFLV has been described in Brazil (Fajardo et al., 2000), the virus was not present in these samples (data not shown). The cause of the yellow speckle symptoms observed in 'Niagara Rosada' and its relationship to CEVd and HSVd have still to be investigated. On the other hand, the isolates present several nucleotide changes dispersed in

TABLE 2 - HSVd and CEVd variants from grapevine and citrus, their origin and accession numbers. The grapevine variants characterized in this paper are indicated in grey

\begin{tabular}{|c|c|c|c|c|c|c|c|}
\hline & HSVd variants & Origin & Accession numbers & & CEVd variants & Origin & Accession numbers \\
\hline \multirow[t]{14}{*}{ Grapevine } & HCSC10 & Brazil & DQ444475 & Grapevine & CSC07 & Brazil & DQ444473 \\
\hline & HCSC01 & Brazil & DQ471997 & & CSC09 & Brazil & DQ471994 \\
\hline & HCSC08 & Brazil & DQ471998 & & CSC10 & Brazil & DQ471995 \\
\hline & HNiagD08 & Brazil & DQ444476 & & CSC11 & Brazil & DQ471996 \\
\hline & HSVd-RXX & Germany & X06873 & & NiagD11 & Brazil & DQ444474 \\
\hline & HSVd-IIA & Germany & X87928 & & CEVd-g & Spain & Y00328 \\
\hline & HSVd-IE & Germany & X87927 & & & & \\
\hline & HSVd-IA & Germany & X87924 & $\underline{\text { Citrus }}$ & CEVd-HB & China & AY456136 \\
\hline & HSVd-IC & Germany & X87925 & & CEVd-dgM & USA & AF298178 \\
\hline & HSVd-Hung & Hunga ry & Y14050 & & CitE01 & Brazil & - \\
\hline & HSVd-IB & Germany & X87923 & & CitE02 & Brazil & - \\
\hline & HSVd-SHV & Japan & M35717 & & CEVd-01 & - & J02053 \\
\hline & HSVd-ID & Germany & X87926 & & CEVd-02 & Australia & M34917 \\
\hline & & & & & CEVd-03 & Australia & K00964 \\
\hline \multirow[t]{7}{*}{ Citrus } & HSVd-Cit01 & - & X06718 & & CEVd-30 & Israel & U21126 \\
\hline & HSVd-Cit02 & - & X06719 & & CEVd-43 & Brazil & AF434678 \\
\hline & HSVd-Cit03 & - & X13838 & & CEVd-46 & Japan & AB054592 \\
\hline & HSVd-Cit33 & Uruguay & AF359276 & & CEVd-205E1 & Uruguay & AF428058 \\
\hline & HSVd-Cit42 & Uruguay & AF416554 & & CEVd-205E5 & Uruguay & AF428060 \\
\hline & HSVd-Cit41 & USA & X69518 & & & & \\
\hline & HSVd Cit46 & Brazil & AF434679 & & & & \\
\hline
\end{tabular}




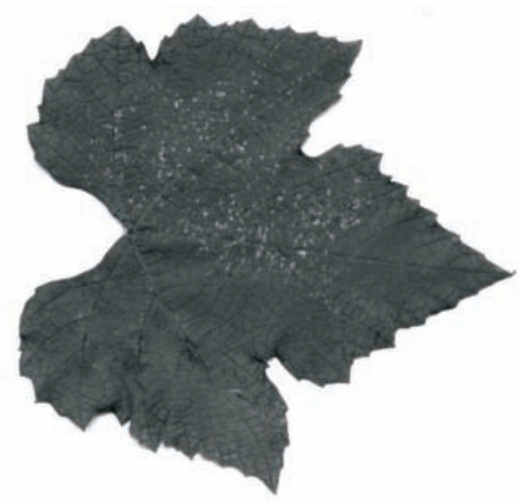

FIG. 1 - Leaf of Vitis labrusca 'Niagara Rosada' doubly infected by HSVd and CEVd showing yellow speckle symptoms.

all structural domains in the molecule (Figure 2), which could influence symptom expression (Sano et al., 1992).

Sequence comparisons of the clones obtained revealed a high identity to CEVd and HSVd variants deposited in the "Subviral RNA Database" (http://subviral.med.uottawa.ca/ cgi-bin/accueil.cgi?typeRNA=1). The predicted secondary structures of minimal energy proposed for the two HSVd and two CEVd variants sequenced in this work, and the nucleotide differences observed among the clones are shown for the two viroid species (Figure 2). For the HSVd clones (HCSC10 and HNiagD08) and the HSVd-SHV grapevine variant, a total of 27 nucleotides changes were observed, with 6 differences noted in the TL domain, and 2, 8, 2 and 9 in the P, C, V and TR domains, respectively (Figure 2A). Interestingly, these changes affected neither the secondary structure nor the TCH motif and the main nucleotides in the CCR domain (data not shown). On the other hand, in contrast to previous results for citrus HSVd isolates (Palacio-Bielsa et al., 2004), we observed some changes in the $\mathrm{C}$ domain for the grapevine HSVd clones analyzed here.

For CEVd, 53 differences were observed among CSC07, NiagD11 and CEVd-g, with 7 changes in the TL domain, and 10, 9, 17 and 10 changes in the P, C, V and TR domains, respectively. In this case, the nucleotide changes did not affect the main secondary structure (Figure 2B). The main changes were observed in the loops and in non-basepaired nucleotides. Some of the changes were compensatory; for example, in the CEVd secondary structure, in residues $137(\mathrm{C} \rightarrow \mathrm{U}), 227(\mathrm{G} \rightarrow \mathrm{A}), 273(\mathrm{G} \rightarrow \mathrm{U})$ and $302(\mathrm{U} \rightarrow \mathrm{C})$, base pairing was restored. The TCR was also preserved, as well as the main nucleotides in the $\mathrm{C}$ domain. We also observed high variability in the $\mathrm{V}$ domain and low variability in the TL domain, confirming a previous report (Gandía et al., 2005). These authors have also observed that most changes in the $\mathrm{CEVd}$ molecule were located in the $\mathrm{P}$ domain, resulting in an increase in the size of the loops. The changes in the nucleotide sequences observed in the clones sequenced in this work (Figure 2) suggest that both grapevine viroids (CEVd and HSVd) follow a quasispecies model as demonstrated by Gandía et al. (2005) for citrus CEVd isolates.
It was observed, by phylogenetic analysis based on multiple alignments of the HSVd and CEVd variants, that the four Brazilian grapevine HSVd clones clustered with other grapevine HSVd variants. They formed a specific group separated from a second one formed by citrus variants, with a unique exception formed by the HSVd-SHV grapevine isolate, which is more similar to the citrus isolates (Figure 3). The HNiagD08 variant from 'Niagara Rosada' was separated from the other grapevine viroid variants in the tree (Figure 3 ). This might be due to evolution and consequent adaptation of this viroid variant to a new plant genotype (in this case, V. labrusca 'Niagara Rosada'), or could represent a viroid sequence that probably does not share the same geographical origin. Sano et al. (2001) suggested that HSVd in hops may represent a transition stage in which a viroid originated in grapevine is in the process of adaptation to a new host and therefore is more aggressive and can induce symptoms. HSVd variants have been divided into three groups based on their sequence identity and phylogenetic analyses: (i) grapevine and hop group; (ii) citrus group; and (iii) almond, apricot, peach and plum group (Sano et al., 2001). These authors have suggested that hop disease had its origin in grapevine by a "jump" of the pathogen from the latter to the former. Bar-Joseph (2003) has also suggested the possible grapevine origin of the citrus viroids, including HSVd. This connection between grapevine and citrus viroids is probably due to the prolonged vegetative propagation of grapevines throughout Asia and Middle East before the introduction of citrus in these regions.

Although two main clades (with high bootstrap values) were formed in the phylogenetic tree (Figure 4), the Brazilian CEVd variants did not form specific groups and no relationship between the variants and geographical origin was observed, although all Brazilian grapevine variants cluster in the same clade (Figure 4). Our analyses were done with grapevine variants of CEVd sequenced in this work and the grapevine variant from Spain (CEVd-g) (GarcíaArenal et al., 1987), which is the only variant of CEVd from grapevine deposited in the "Subviral RNA Database".

The sequence variability of HSVd and CEVd variants characterized in this work was previously noticed only for HSVd isolates in grapevine (Sano et al., 2001). The genetic structure and diversity characterization of viroid variants is very important to understand viroid evolution and to assess the real status of the population of RNA molecules in the plant. As demonstrated here, both HSVd and CEVd follow a quasispecies structure, which means a permanent modification of the RNA population. In spite of this variability, the long-term infection of these viroids in grapevine suggests that the viroid-host interactions may play a selective pressure for viable RNA molecules, preserving the main conserved motifs. These aspects were demonstrated in the RNA genomes of both species (HSVd and CEVd) analyzed, which presented regions of the molecule with a high degree of conservation, while some regions were more variable (Figure 2). This knowledge is important to connect 

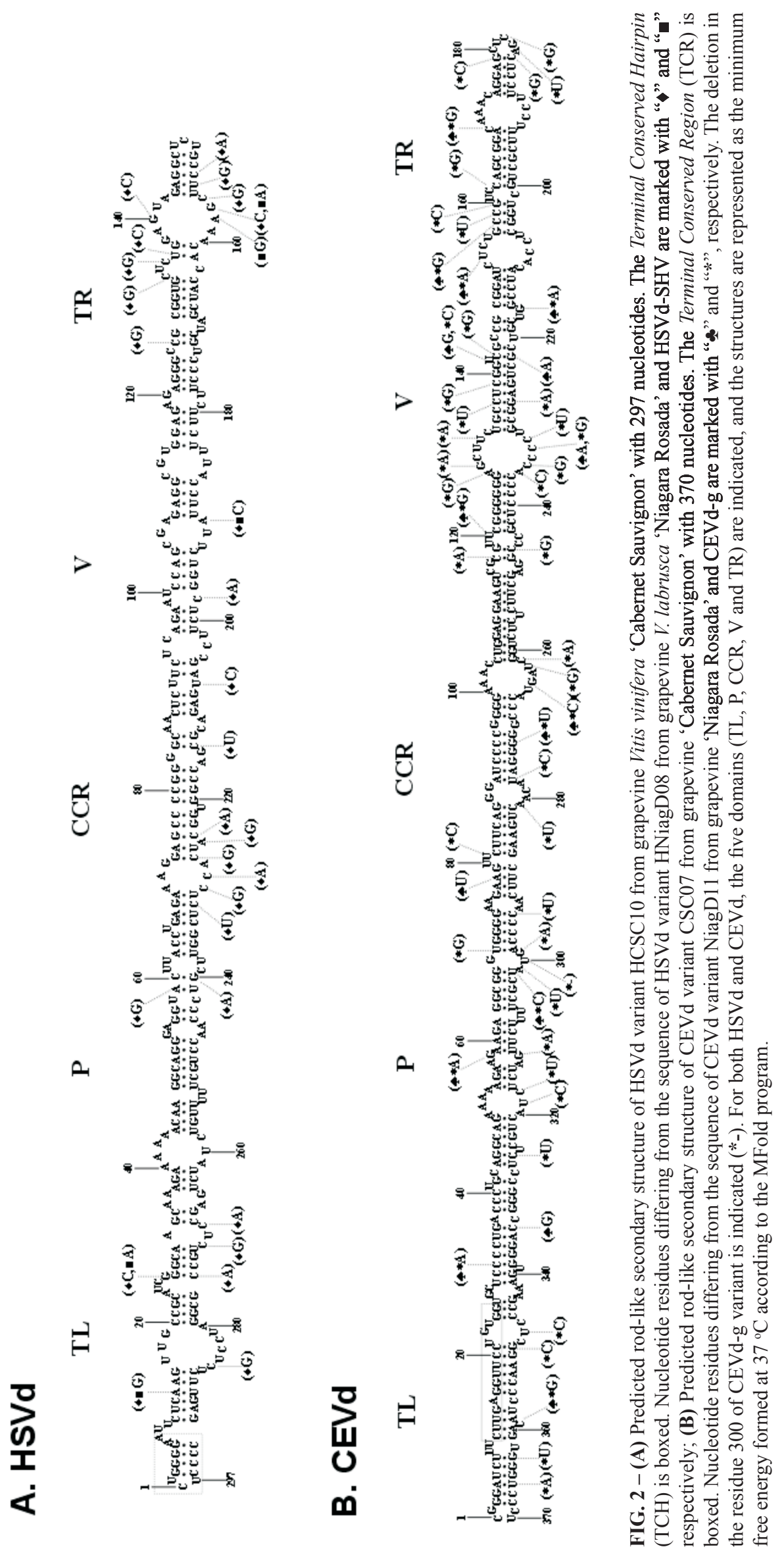


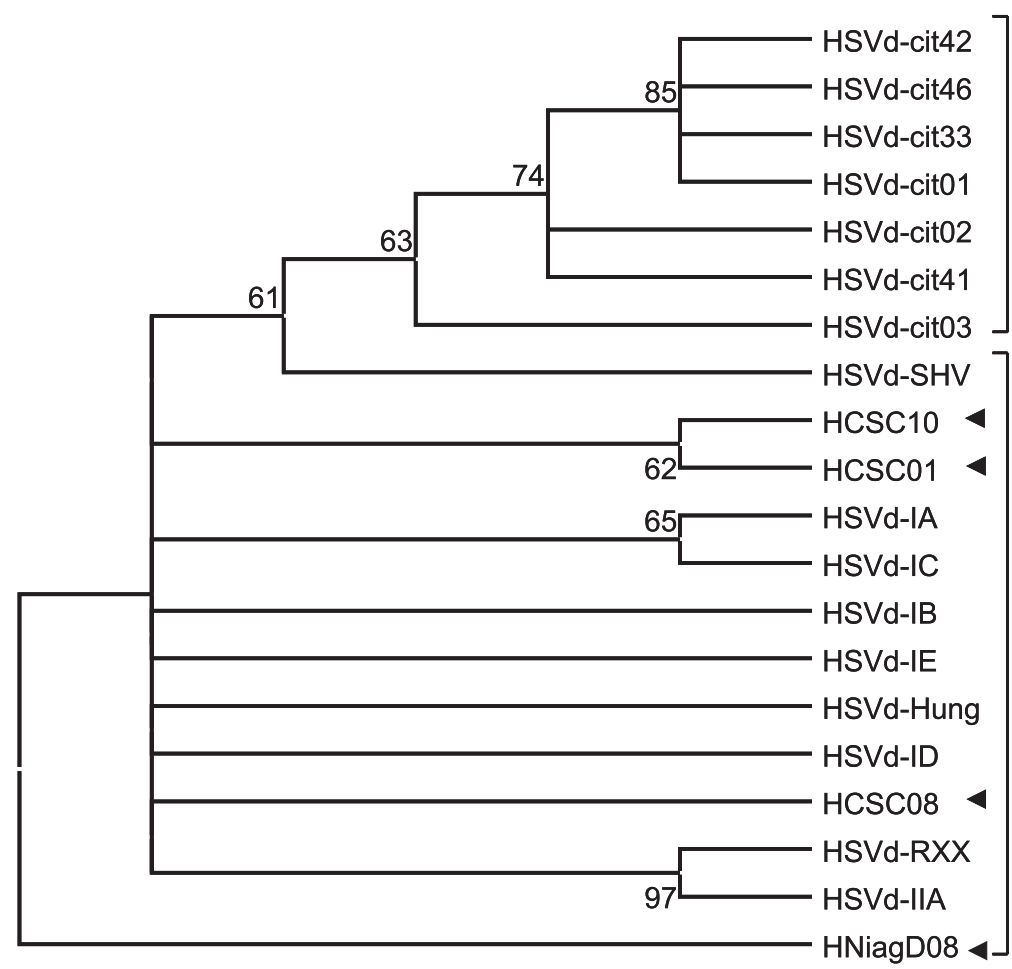

\section{Citrus}

variants

Grapevine variants
FIG. 3 - Neighbor-joining unrooted tree obtained with the MEGA 3.2 program based on the multiple alignment of grapevine and citrus HSVd nucleotide sequences. HCSC01, HCSC08 and HCSC10 correspond to clones from grapevine Vitis vinifera 'Cabernet Sauvignon' and HNiagD08 corresponds to a clone from grapevine $V$. labrusca 'Niagara Rosada' variants from Brazil (black arrows). Two main clusters are formed, one with citrus and another with grapevine viroids variants, except for the HSVd-SHV grapevine variant which clustered among the citrus variants. Bootstrap values for 2000 replications are shown in the branches. The GenBank accession numbers of the isolates are shown in Table 2.

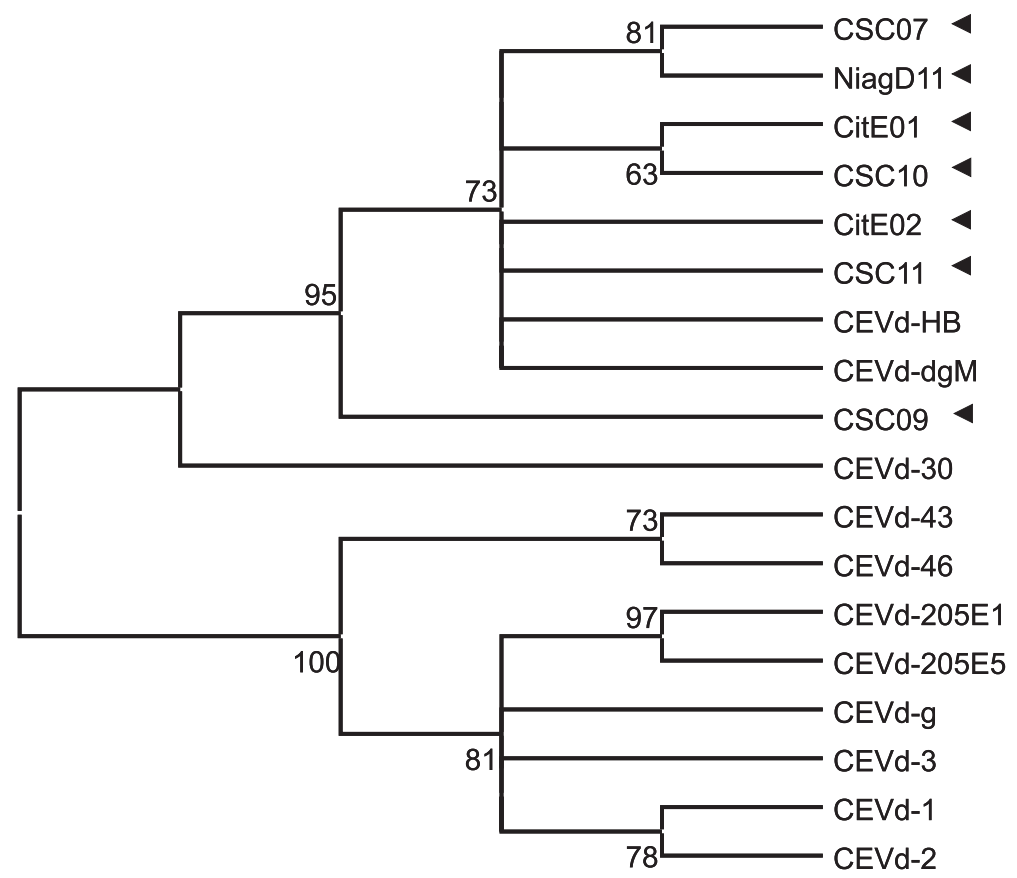

FIG. 4 - Neighbor-joining unrooted tree obtained with MEGA 3.2 program based on the multiple alignment of grapevine and citrus CEVd nucleotide sequences. CSC07, CSC09 CSC10 and CSC11 correspond to clones from grapevine Vitis vinifera 'Cabernet Sauvignon' samples and NiagD11 corresponds to a clone from grapevine $V$. labrusca 'Niagara Rosada' from Brazil. CitE01 and CitE02 are CEVd citrus isolates from São Paulo also sequenced in this work (black arrows). Bootstrap values for 2000 replications are shown in the branches. The GenBank accession numbers of the isolates are described in the Table 2. the effect of the nucleotide sequence in symptom expression and also to evaluate different molecular techniques for viroid detection that can be used for indexing programs.

It is noteworthy that the presence of the grapevine and citrus viroids in our conditions is attributed to the introduction of vegetative material from other countries. The control of these pathogens in grapevines in other countries such as the United States, Australia, Spain and Italy is based on indexing programs using molecular methods for viroid detection and a clean stock program specifically designed to collect, maintain and distribute viroid-free propagation material for farmers. In Brazil, a clean stock program offering viroid-tested propagation materials is applied only for citrus viroids. 
We have found a high genetic variability in the samples analyzed, but the status of the viroids infecting grapevines in Brazil remains uncertain. Given that viroids are spread worldwide in grapevine, it is possible that they are also widespread in Brazilian vineyards. Therefore, a survey for grapevine viroids based on the methods used here will allow us to further evaluate the genetic variability and geographical distribution of these pathogens in Brazil.

\section{ACKNOWLEDGEMENTS}

The authors would like to acknowledge Dr. M.C. Gonçalves (Lab. Fitovirologia e Fisiopatologia, Instituto Biológico, São Paulo, Brazil) for critical review and comments on this manuscript.

\section{REFERENCES}

BAR-JOSEPH, M. Natural history of viroids - horticultural aspects. In: Hadidi, A., Flores, R., Randles, J.W. \& Semancik, J.S. Viroids. CSIRO Publishing, Australia. p.246-251. 2003.

DE RIJK, P. \& DE WACHTER, R. RNA Viz, a program for the visualization of RNA secondary structure. Nucleic Acids Research 25:4679-4684. 1997.

FAJARDO, T.V.M., KUHN, G.B., EIRAS, M. \& NICKEL, O. Caracterização parcial de um isolado do Grapevine fanleaf virus. Fitopatologia Brasileira 25:505-511. 2000.

FLORES, R., DURAN-VILA, N., PALLÁS, V. \& SEMANCIK, J.S. Detection of viroid and viroid-like RNAs from grapevines. Journal of General Virology 66:2095-2102. 1985.

FLORES, R., HERNANDEZ, C., MARTÍNEZ DE ALBA, A.E., DARÓS, J.A. \& DI SERIO, F. Viroids and viroid-host interactions. Annual Review of Phytopathology 43:117-139. 2005a.

FLORES, R., RANDLES, J.W., OWENS, R.A., BAR-JOSEPH, M. \& DIENER, T.O. Viroidae. In: Fauquet, C.M., Mayo, M.A., Maniloff, J., Desselberger U. \& Ball, A.L. (Eds.) Virus Taxonomy, Eighth Report of the International Committee on Taxonomy of Viruses. London. Elsevier Academic Press. 2005b. pp. 1145-1159.

FONSECA, M.E.N. \& KUHN, G. Natural infection of grapevine by Citrus exocortis viroid and Hop stunt viroid in Brazil. Fitopatologia Brasileira 19:285. 1994. (Abstract)

GANDÍA, M., RUBIO, L., PALACIO, A. \& DURAN-VILA, N. Genetic variation and population structure of an isolate of Citrus exocortis viroid (CEVd) and of the progenies of two infectious sequence variants. Archives of Virology 150:1945-1957. 2005.

GARCÍA-ARENAL, F., PALLÁS, V. \& FLORES, R. The sequence of a viroid from grapevine closely related to severe isolates of citrus exocortis viroid. Nucleic Acids Research 15:4203-4210. 1987.

KUMAR, S., TAMURA, K. \& NEI, M. MEGA3: Integrated software for Molecular Evolutionary Genetics Analysis and sequence alignment.
Briefings in Bioinformatics 5:150-163. 2004.

LITTLE, A. \& REZAIAN, M.A. Grapevine viroids. In: Hadidi, A., Flores, R., Randles, J.W. \& Semancik, J.S. Viroids. CSIRO Publishing, Australia. pp.195-206. 2003.

NICHOLAS, K.B., NICHOLAS, H.B. \& DEERFIELD, D.W. II. GeneDoc: Analysis and visualization of genetics variation. EMBNEW News 4: 14. 1997.

PALACIO-BIELSA, A., ROMERO-DURBÁN, J. \& DURANVILA, N. Characterization of citrus HSVd isolates. Archives of Virology 149:537-552. 2004.

REZAIAN, M.A., KOLTUNOW, A.M. \& KRAKE, L.R. Isolation of three viroids and a circular RNA from grapevines. Journal of General Virology 69:413-422. 1988.

REZAIAN, M.A., KRAKE, L.R. \& GOLINO, D.A. Common identity of grapevine viroids from USA and Australia revealed by PCR analysis. Intervirology 34:38-43. 1992.

ROWHANI, A., CHAY, C., GOLINO, D.A. \& FALK, B.W. Development of a polymerase chain reaction technique for the detection of grapevine fanleaf virus in grapevine tissue. Phytopathology 83:749-753. 1993.

SANO, T., CANDRESSE, T., HAMMOND, R.W., DIENER, T.O. \& OWENS, R.A. Identification of multiple structural domains regulating viroid pathogenicity. Proceedings of the National Academy of Sciences of the USA 89:10104-10108. 1992.

SANO, T., MIMURA, R. \& OHSHIMA, K. Phylogenetic analysis of hop and grapevine isolates of Hop stunt viroid supports a grapevine origin for hop stunt disease. Virus Genes 22:53-59. 2001.

SANO, T., OSHIMA, K., HATAYA, T., UYEDA, I., SHIKATA, E., CHOU, T., MESHI, T. \& OKADA, Y. A viroid-like RNA isolated from grapevine has high sequence homology with hop stunt viroid. Journal of General Virology 66:333-338. 1985.

SEMANCIK, J.S. \& SZYCHOWSKI, J.A. Relationships among the viroids derived from grapevines. Journal of General Virology 73:1465-1469. 1992.

SHIKATA, E., SANO, T. \& UYEDA, I. An infectious low molecular weight RNA was detected in grapevines by molecular hybridisation with hop stunt viroid cDNA. Proceedings of Japan Academy Ser. B 60:202. 1984.

SINGH, R.P., READY, K.F.M. \& NIE, X. Biology. In: Hadidi, A., Flores, R., Randles, J.W. \& Semancik, J.S. Viroids. CSIRO Publishing, Australia. 2003. pp. 30-48.

SZYCHOWSKI, J.A., McKENRY, M.V., WALKER, .A., WOLPERT, J.A., CREDI, R. \& SEMANCIK, J.S. The vein-banding disease syndrome: a synergistic reaction between grapevine viroids and fanleaf virus. Vitis 34:229-232. 1995.

TARGON, M.L.P.N., MULLER, G.W., CARVALHO, S.A., DE SOUZA, J.M. \& MACHADO, M.A. Detecção de viróides em citros através de hibridização de impressões de tecidos. Summa Phytopathologica 29:60. 2003. (Resumo)

ZUKER, M. On finding all suboptimal foldings of an RNA molecule. Science 244:48-52. 1989. 